\title{
Mechanical Properties of Geopolymer Grout with Bagasse Ash and Resin Catalyst
}

\author{
Siti Isnaini Kurniawati Djaha ${ }^{1,3}$, Hakas Prayuda ${ }^{2}$, Fanny Monika² ${ }^{2}$ Martyana Dwi Cahyati ${ }^{2}$, \\ Fadillawaty Saleh ${ }^{2}$ \\ \{isnainidjaha@gmail.com, hakasprayuda@umy.ac.id, fanny.monika.2007@ft.umy.ac.id, \\ martyana.dc@gmail.com,dilla_vu@yahoo.com\} \\ ${ }^{1}$ Department of Civil Engineering, Faculty of Engineering, Akademi Teknik Kupang, Nusa Tenggara \\ Timur, Indonesia. \\ ${ }^{2}$ Department of Civil Engineering, Faculty of Engineering, Universitas Muhammadiyah Yogyakarta, \\ Tamantirto, Kasihan, Bantul, Daerah Istimewa Yogyakarta, 55183 \\ ${ }^{3}$ Balai Jalan Nasional X Kupang. Department of Bina Marga, Kupang, Nusa Tenggara Timur, \\ Indonesia
}

\begin{abstract}
Concrete can crack which causes a decrease of performance in the structure of the building. It requires an improvement in the damage in the concrete so that the strength returns to normal. This research was conducted to find a mixture of materials with the appropriate composition in order to restore the strength of the damaged concrete by using a new mixture modification. The material used in this study is using bagasse ash derived from sugar mill waste and chemical resin catalyst as a substitute for water and binder. The mixture was made using 5 variations in the volume ratio of catalyst resin and bagasse ash, namely 1: $0.4,1: 0.53,1: 0.67,1: 0.8$, and $1: 1$. This research tested the mechanical properties of the specimens that have been made from the mix proportion. The result of the research that has been shown is that the addition of sugarcane ash in a mixture with resin catalyst levels continues to increase in the compressive strength. The increasing age of the concrete also increases the value of compressive strength on the specimens. The highest compressive strength is obtained by mixing material with a ratio of 1 : 1 , it was 96.18 MPa. The grouting material that has been made is also less effective when injected into damaged parts of the concrete because it has a thick texture which makes the material difficult to inject so that it requires greater pressure than the grout material from a mixture of cement and water
\end{abstract}

Keywords: Grouting, Mechanical Properties, Bagasse Ash, Resin Catalyst.

\section{Introduction}

Concrete structure is one important component in the sustainability of infrastructure in the world. All countries in the world use concrete as one of the main materials in the construction of infrastructure such as buildings, bridges and roads [1]. Concrete constituent components are generally composed of aggregates, cement and water, which produce a pretty good compressive strength besides easy to produce $[1,2]$. Durability in concrete is influenced by various factors. If the value of elastic strain exceeds tensile strain capacity, then cracks will begin to occur in the concrete [3]. This cracking process can be caused by shrinkage and creeps and other factors. If the crack is left continuously, it will be probable that the crack width will increase. As time 
goes by, the crack will reduce the value of the structure durability. In reinforced concrete structures, this case will cause the steel reinforcement in the concrete to corrode which is certainly very bad for the structure. Through these problems, of course, cracks must be repaired, one of the methods used to repair cracks is by grouting.

In general, the constituent material for grouting consists of grout cement and water. Grouting or retrofitting process is by inserting a thin enough cement paste into the crack in the concrete. The advantage of this method is that it is very fast for the repair process. The strength of grouting material usually has a fairly high initial compressive strength. The use of grouting is very suitable for buildings which are cracked due to an earthquake or for structures which have cracked due to shrinkage and creeps. Application of grouting has also been made in real construction, both conventional grouting and using special methods grouting. Some research results show that grouting technology has been applied to shield tunnel construction [4-6], offshore wind turbine $[7,8]$, Drainage pipe $[9,10]$, repairs to beams, columns, plates and beamcolumn connections [11-15], and is used to connect connections to prestressed concrete [16, 17].

Besides using conventional methods, the concept of grouting continues to develop. The development of the concept of composing grouting material is also inseparable from innovation with the use of eco-materials so producing grouting, which is more environmentally friendly. This research will use the innovation of the use of bagasse ash as a constituent of grouting mixed with catalyst resin as a binding agent to produce grout geopolymers. In previous studies, many have developed concepts like this by using other waste materials such as fly ash [18-20] and bottom ash [21]. In addition, the use of resins as grouting and mortar materials has also been widely conducted, including using polyester resin [22, 23], polymeric resin [24], and epoxy resin [25].

The use of Bagasse Ash as a construction material is one of the innovations which quite rapidly develop. In the previous research phase, innovation has been carried out with the use of bagasse ash as construction material, including the use of bagasse ash for making mortars [2628]. This research will utilise bagasse ash and catalyst resin as basic material for making grouting. The test consists of a fresh properties test and a hardened properties test, in the fresh properties condition, the examination of the spread value or flowability, a thickness value and a time setting will be performed. Meanwhile, in the hardened conditions, the examination of unit weight and compressive strength will be performed at the age of 3, 7, 14 and 38 days. The mixture variations used in this study were $60,80,100,120$ and $150 \mathrm{ml}$ bagasse ash using the same volume of resin in each mixture. Through this research, it is expected to utilise bagasse ash waste which has not been used optimally in Indonesia to become material of economic value.

\section{Experimental Program}

This study used an experimental method based on laboratory testing. In this section, the material and mix proportion, and the method of testing on each test object will be explained. The material used in this study consisted of bagasse ash and resin catalyst. The test consisted of flowability, viscosity value, setting time, unit weight and compressive strength. Bagasse ash used in this study came from sugar processing waste in Bantul, Yogyakarta, Indonesia.

\subsection{Material and Mix Proportion}

This study used two main materials, namely bagasse ash and resin catalyst. Resins are chemicals with a thick texture and can harden if dropped with a catalyst. The more catalysts dropped, the faster the mixture will harden. Bagasse is a material used as a substitute for cement obtained from the burning of sugarcane bagasse from sugar production waste. Bagasse ash has 
been widely applied in previous studies that have been explained in the introduction. This study used five variations of bagasse ash using the volume control. Table 1 shows the variation of the mixture used in this study.

Table 1 Comparison of mixed compositions

\begin{tabular}{cccc}
\hline & Comparison & \multicolumn{2}{c}{ a volume unit $(\mathrm{ml})$} \\
ID & & Resin & Bagasse Ash \\
\hline G1 & $1: 0,4$ & 150 & 60 \\
G2 & $1: 0,53$ & 150 & 80 \\
G3 & $1: 0,67$ & 150 & 100 \\
G4 & $1: 0,8$ & 150 & 120 \\
G5 & $1: 1$ & 150 & 150 \\
\hline
\end{tabular}

\subsection{Method of Testing}

In this study, testing fresh properties was in the form of flowability, thickness value and time setting. As for the hardened properties test, unit weight and compressive strength tests will be performed. Compressive strength testing was carried out at day 3, 7, 14 and 28. Flowability testing was conducted shortly after finishing the mixing each material. This flowability test aims to determine the ability of the material to flow to meet parts that are difficult to compact.

\section{Result and Discussion}

\subsection{Fresh Properties}

Flowability test was carried out for each variation, as shown in Figure 1. The results show that if the amount of bagasse ash increases, the flowability value of the grouting material will be decreased. Bagasse ash mixture of $60 \mathrm{ml}$ produced a flowability value of $342.5 \%$; the value continues to decrease as the amount of bagasse ash increased. In a 1: 1 mixture, bagasse ash of $150 \mathrm{ml}$ for each specimen produces a flowability value of $280 \%$. Flowability value will decrease as bagasse ash increases. This is because bagasse ash which is dry enough to absorb the resin during the stirring process makes the mixture more difficult to spread. It is important to pay attention to the standards for the minimum requirements for flowability that are allowed if this material is used for grouting in construction projects.

The thickness test was also done by measuring the time of fresh grouting flowing through the funnel that has been determined according to the standard. Figure 2 is the result of thickness testing on concrete. The greater the value indicates that the grouting material is thicker and more difficult to flow or increasingly requires great pressure to be injected into the concrete if the grouting is used to repair the concrete. The test results show that the more the bagasse ash value increases the thickness value will increase, and the more time it takes to flow. When using 60 $\mathrm{ml}$ bagasse ash, fresh grouting can flow with 7.42 seconds, while using 1: 1 proportion, the fresh grouting flow time will be 32.07 seconds. The faster the flow time, the better it is for fresh grouting, with increasing bagasse ash, a load of liquid resin will increase to bring the solid mass to the empty pores.

The last fresh properties test is the setting time test, which aims to find out the final time of grouting material becomes hard. The results in Figure 3 show that the more the amount of the bagasse ash, the faster the setting time will be resulted. In a $60 \mathrm{ml}$ bagasse ash mixture, it takes 552 minutes to harden. Meanwhile, when using $150 \mathrm{ml}$ bagasse ash, it takes 300 minutes only 
to harden. This phenomenon occurred because the more bagasse ash is used, the more resin is absorbed then, it will harden faster. The setting time has a crucial role in the hydration process of grouting material. Sooner or later, the hardening process becomes an important consideration.

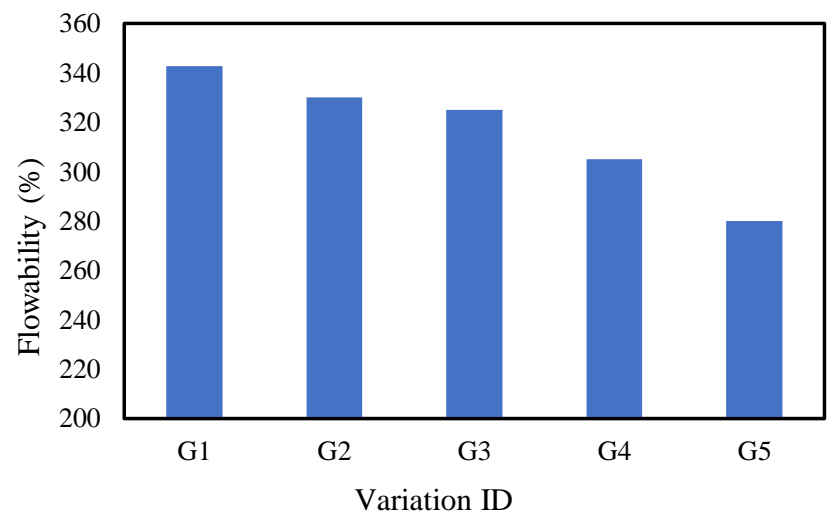

Fig 1. Flowability result for each variation

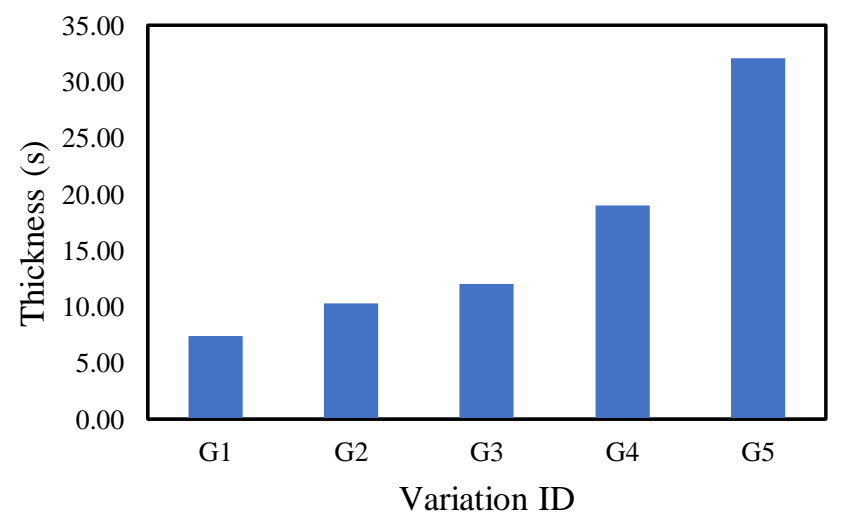

Fig 2. Thickness result for each variation

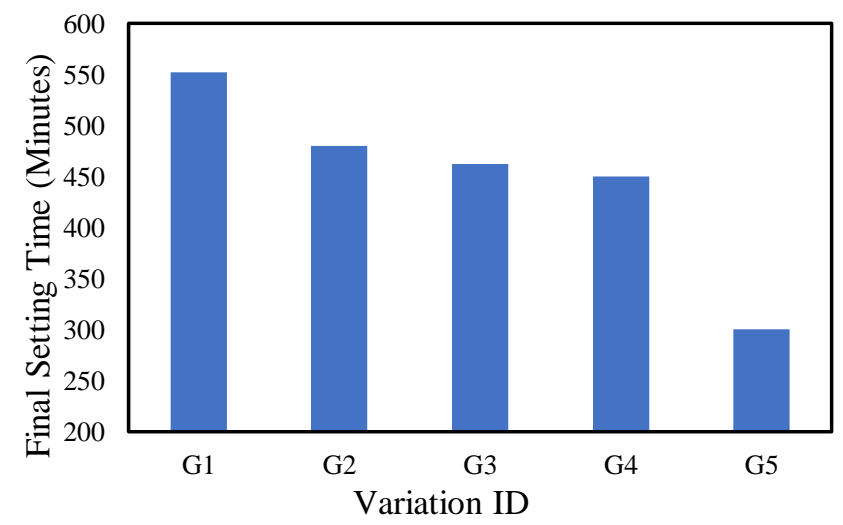


Fig 3. Final setting time for each variation

\subsection{Hardened Properties}

The unit weight test is also carried out to determine the weight produced. In the $60 \mathrm{ml}$ bagasse ash mixture, it provides $1.4 \mathrm{gr} / \mathrm{cm} 3$. At the same time, in the other combinations, it was obtained a unit size ranging from $1-1.2 \mathrm{gr} / \mathrm{cm} 3$. Fig. 4 is the result of unit weight test.

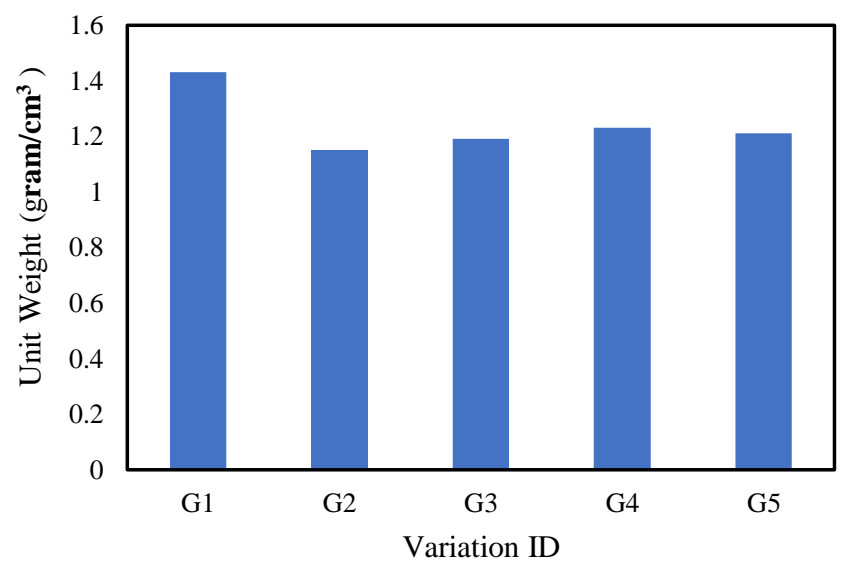

Fig 4. Unit weight for each variation

The compressive strength test was carried out at 3, 714 and 27 days. Figure 5 is the result of the relationship between compressive strength and curing time. In this test, the curing was carried out by using water curing for 28 days. The compressive strength of the specimen with a size of $5 \times 5 \times 5 \mathrm{~cm}$ in each result for each variation consists of 3 specimens. In Figure 5, it can be seen that the more the amount of bagasse ash, the higher the value of the compressive strength. However, for the age of 28 days, the compressive strength produced does not have a significant difference among the variations.

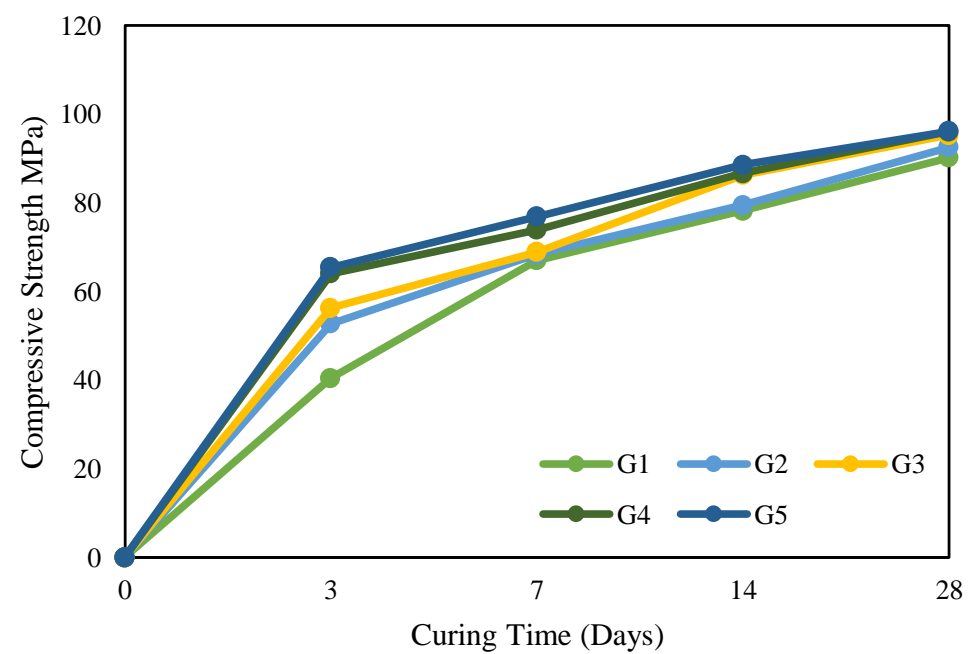

Fig 5. Compressive strength vs curing time 
Figure 6 shows the relationship between each variation on the compressive strength produced at 28 days and three days. Figure 6(a) shows the increasing amount of bagasse ash used; the compressive strength produced will increase. In a mixture of $60 \mathrm{ml}$ bagasse ash, the compressive strength produced is $90 \mathrm{MPa}$ at 28 days. Meanwhile, a 150ml bagasse ash mixture provides a compressive strength of $96.18 \mathrm{Mpa}$. This result indicates an increase of $6.87 \%$. Moreover, at the age of 3 days, a mixture of $60 \mathrm{ml}$ bagasse ash has a compressive strength of $40.38 \mathrm{Mpa}$ while a $150 \mathrm{ml}$ mixture produces a compressive strength of $65.43 \mathrm{Mpa}$. This result shows a significant increase, which is equal to $62.05 \%$.

The high early strength concrete indicates that the increasing content of bagasse ash in the mixture will produce a better high early strength concrete even though at the age of 28 days, the compressive strength has an insignificant difference. However, the level of flowability and workability need to be focused because if there is excessive content of bagasse ash, then the level of dilution from grouting will decrease. As a consequence, the material will be difficult to be processed.

Also, several focus things are the level of refinement of bagasse ash, the finer the bagasse ash, the value of flowability in fresh grouting will increase because the level of dilution will be better. Thus, good compressive strength and fresh properties can be obtained. In this study, several tests were also carried out, including absorption and moisture content, but the excess of resin catalyst which did not absorb water caused the absorption results to be absent. It is better for further research to have the test of durability and absorption in a long time; then, the durability of this type of grouting can be known. The use of $150 \mathrm{ml}$ bagasse ash is the maximum level that can be used. The higher the bagasse ash used, the less good the value of fresh properties.

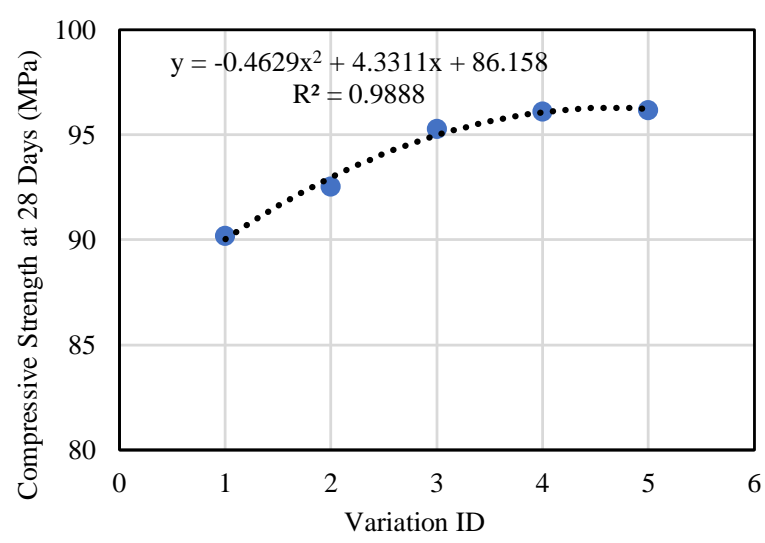

(a)

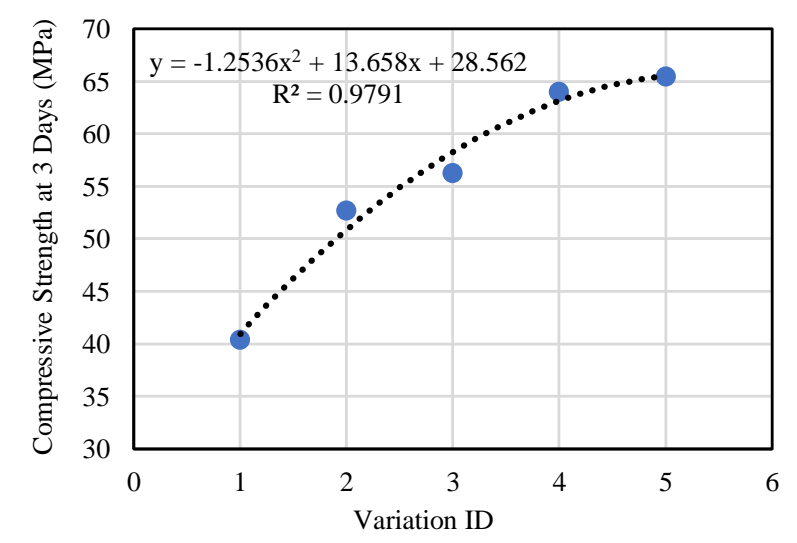

(b)

Fig 6. The relationship between compressive strength and amount of bagasse ash (a) 28 days

(b) 3 days

\section{Conclusion}

Based on the results of the study, it can be concluded that the more bagasse ash is used, the value of flowability will decrease, and the level of viscosity will increase. This result shows that there are restrictions on the use of bagasse ash as grouting material. Although the compressive 
strength results indicate that the more bagasse ash used will produce a higher compressive strength, specifically for the initial compressive strength of 3 days. However, the use of $150 \mathrm{ml}$ content of bagasse ash is still very acceptable for grouting material.

Acknowledgements. The authors would like to thank the research team, i.e., Axlla Femmy Wahyundita, Diyat Adi Muliawan and Bagas Chrisma Primady. In addition, a thank you was also conveyed to the Laboratory material construction staff of the Civil Engineering Department, Faculty of Engineering, Universitas Muhammadiyah Yogyakarta.

\section{References}

[1] Tittelboom, K. V., and Belie, N. D.: Self-healing cementitious materials - a review. Materials. Vol 6, pp. 2182-2217 (2003).

[2] Tittleboom, K. V., Belie, N. D., Muynck, W. D., and Verstraete, W.: Use of bacteria to repair the crack in the concrete. Cement and Concrete Research. Vol 40, pp. 157-166 (2010).

[3] Lam, N. T., Sumranwanich, T., Krammart, P., Yodmalai, D., Sahamitmongkol, R., and Tangtermsirikul, S.: Durability properties of concrete with expansive additive. Research Development Journal. Vol 19, pp. 8-15 (2008).

[4] Zhang, D., Huang, Z., Wang, R., Yan, J., and Zhang, J.: Grouting based treatment of tunnel settlement: practice in Shanghai. Tunnelling and Underground Space Technology. Vol 80, pp. 181-196 (2018).

[5] Jin-long, L., Hamza, O., Davies-Vollum, K. S., and Jie-qun, L.: Repairing a shield tunnel damaged by secondary grouting. Tunnelling and Underground Space Technology. Vol 80, pp. 313-321 (2018).

[6] Ding, W., Duan, C., Zhu, Y., Zhao, T., Huang, D., and Li, P.: The behavior of synchronous grouting in a quasi-rectangular shield tunnel based on a large visualized model test. Tunnelling and Underground Space Technology. Vol 83, pp. 409-424 (2019).

[7] Chen, T., Li, Z., Wang, X., Yuang, G., and Liu, J.: Experimental study on the ultimate bending performance of grouted connections in offshore wind turbine support structures. Thin-Walled Structures. Vol 132, pp. 522-536 (2018).

[8] Chen, T., Wang, X., Gu, X., Zhao, Q., Yuan, G., and Liu, J.: Axial compression tests of grouted connections in jacket and monopile offshore wind turbine structures. Engineering Structures. Vol 196, pp. 1-19 (2019).

[9] Hngyuan, F, Bin, ., Fuming, W., Yuke, W., Can, C.: The mechanical behaviour of drainage pipeline under traffic load before and after polymer grouting trenchless repairing. Tunnelling and Underground Space Technology. Vol 74, pp. 185-194 (2018).

[10] Wang, R., Wang F., Xu, J., Zhong, Y., and Li, S.: Full-scale experimental study of the dynamic performance of buried drainage pipes under polymer grouting trenchless rehabilitation. Ocean Engineering. Vol 181, pp. 121-133 (2019).

[11] Thanoon, W. A., Jaafar, M. S., Kadir, M. R. A., and Noorzaei, J.: Repair and Structural Performance of Initiallity cracked reinforced concrete slabs. Construction and Building Materials. Vol 19, pp. 595-603 (2005).

[12] Tsonos, A. G.: Seismic repair of exterios R/C beam to column joints using two-sided and three-sided jackets. Structural Engineering and Mechanics. Vol 13, pp. 17-34 (2002).

[13] Jumaat, M. Z., Kabir, M. H., and Obaydullah, M.: A review of the repair of reinforced concrete beams. Journal of Applied Science Research. Vol. 2, pp. 317-326 (2006).

[14] Hsu, W., Liu C., Shiau, Y., and Lin W.: Discussion on the reinforcement of reinforced concrete slab structures. Sustainability. Vol 11, (2019). 
[15] Mohammed A. A., Manalo, A. C., Maranan, G. B., Zhuge, Y., Vijay. P. V., and Pettigrew, J.: Behavior of damaged concrete columns repaired with vovel FRP jacket. Journal of Composites for Construction. Vol 23, (2019).

[16] Jiang, T., Kong, Q., Wang, W., Huo, L., and Song G.: Monitoring of grouting compactness in a post-tensioning tendod duct using piezoceramic transducers. Sensors. Vol 16, (2016).

[17] Jaeger, B. J., Sansalone, M. J., Poston, R. W.: Detecting voids in grouted tendon ducts of post-tensioned concrete structures using the impact-echo method. Structural Journal. Vol 93, pp. 462-473 (1996).

[18] Adak, D., Sarkar, M., and Mandal, S.: Effect of nano-silica on strength and durability of fly ash-based geopolymer mortar. Construction and Building Materials. Vol. 70, pp. 453459 (2014).

[19] Phoo-ngernkham T., Sata, V., Hanjitsuwan, S., Ridtirud, C., Hatanaka, S., and Chindaprasirt, P.: High calcium fly ash geopolymer mortar containing portland cement for use as a repair material. Construction and Building Materials. Vol 98, pp. 482-488 (2015).

[20] Naghizadeh, A., and Ekolu, S. O.: Method for comprehensive mix design of fly ash geopolymer mortars. Construction and Building Materials. Vol. 202, pp. 704-717 (2019).

[21] Sata, V., Sathomsaowaphak, A., Chindaprasirt, P.: Resistance of lignite bottom ash geopolymer mortar to sulfate and sulfuric acid attack. Cement and Concrete Composited. Vol. 34, pp. 700-708 (2012).

[22] Abdel-Azim, A. A., and Attia, I. A.: Making polymer concrete and polymer mortar using synthesized unsaturated polyested resins from poly (ethylene terephthalate) waste. Polymers for Advanced Technologies. Vol 6, pp. 688-692 (1995).

[23] Mani, P., Gupta, A. K., and Krishnamoorthy, S.: Comparative study of epoxy and polyester resin-based polymer concretes. International Journal Adhesion and Adhesives. Vol 7, pp. 157-163.

[24] Vidales, J. M. M., Hernandez, L. N., Lopes, J. I. T., Flores, E. E. M., and Hernandez, L. S.: Polymer mortars prepared using a polymeric resin and particles obtained from waste pet bottle. Construction and Building Materials. Vol 65, pp. 376-383 (2014).

[25] Colangelo, F., Roviello, G., Ricciotti, L., Ferone, C., and Cioffi, R.: Preparation and Characterization of New Geopolymer epocy resin hybrid mortars. Materials. Vol 6, 29893006 (2013).

[26] Yusuf, M. O., Johari, M. A. M., Ahmad, Z. A., and Maslehuddin, M.: Shrinkage and Strength of Alkaline Activated Ground Steel Slag/Ultrafine Palm Oil Fuel Ash Pastes and Mortars. Materials and Design. Vol 63, pp. 710-718. (2014).

[27] Lim, N. H. A. S., Ismail, M. A., Lee. H. S., Hussin. M. W., Sam. A. R. M., and Samadi, M.: The Effect of High Volume Nano Palm Oil Fuel Ash on Microstructure Properties and Hydration Temperature of Mortar. Construction and Building Materials. Vol 93, pp. 29-34. (2015).

[28] Huseien, G. F., Ismail. M., Tahir, M. M., Mirza, J., Khalid, N. H. A., Asaad. M. Husein. A. A., and Sarbini, N. N.: Synergism between Palm Oil Fuel Ash and Slag: Production of Environmental Friendly Alkali Activated Mortars with Enhanced Properties. Construction and Building Materials. Vol 170, pp. 235-244. (2018). 